\title{
Pemberian Pemahaman Mengenai Perilaku Hidup Bersih Dan Sehat (PHBS) dan Protokol Kesehatan Dalam Bepergian di Masa Pandemi Kepada Masyarakat
}

\author{
Taofik Rusdiana*1, Norisca Aliza Putriana ${ }^{2}$, Muhammad Habil Abrar Alhamdra ${ }^{3}$, Shofiyyah Sayyidah ${ }^{4}$ \\ 1,2 Departemen Farmasetika dan Teknologi Farmasi, Fakultas Farmasi Universitas Padjadjaran \\ ${ }^{3}$ Fakultas Ilmu Sosial dan Ilmu Politik, Universitas Padjadjaran \\ ${ }^{4}$ Fakultas Kedokteran, Universitas Padjadjaran \\ ${ }^{1}$ t.rusdiana@unpad.ac.id , ${ }^{2}$ norisca@ unpad.ac.id, ${ }^{3}$ muhammad17026@mail.unpad.ac.id, ${ }^{4}$ shofiyyah17001@mail.unpad.ac.id
}

\begin{abstract}
Seeing the development of the COVID-19 and the increasing number of new cases, WHO has published several updates, guidelines, and health protocols regarding this pandemic. The government of Indonesia has issued an appeal to the public to follow this health protocol. Various educational posters and videos have been widely published on social media, television stations and other communication media. One of the programs that the government always socializes during this pandemic is the implementation of Perilaku Hidup Bersih dan Sehat (PHBS) or Clean and Healthy Behavior. The purpose of this Virtual Integrative Community Service program is to find out the level of public knowledge about the importance of PHBS and traveling during a pandemic, especially in the AKB era. The methods used in this activity are surveys on community PHBS, surveys regarding travel activities during the pandemic, making PHBS videos and posters, and webinars on the use of herbs as an antistress and immunity enhancer. The partner community in this online KKN PPM activity is the Langensari village community, Solokanjeruk sub-district in particular and the general public who can access social media. The results of the traveling survey showed that out of 441 respondents, around 332 people did not have plans to travel. Of the 332 respondents who chose not to travel, around 229 respondents argued that they did not have a crucial interest, 142 respondents were worried about contracting COVID-19, 50 respondents said they did not have accommodation, and 102 respondents chose to continue traveling / traveling. The results of the PHBS survey are that most respondents have implemented PHBS with the most results being $99.3 \%$, namely the choice of washing hands and using masks. Respondents who answered no to the third question gave answers to the causes of this in the form of lack of access to information (3.4\%), laziness (6.9\%), and lack of care (4.1\%). The group activities of the 25 KKN-PPM Virtual Integrative have been carried out well and can increase community knowledge of PHBS and health protocols when traveling during a pandemic and increase knowledge about the use and manufacture of herbs to increase immunity.
\end{abstract}

Keywords : Knowledge, Health Protocol, COVID-19 pandemic, Travel During a Pandemic

Abstrak

Melihat perkembangan pandemi COVID-19 dan angka kasus baru yang terus meningkat, WHO telah mengeluarkan beberapa protokol kesehatan. Pemerintah Indonesia, pemerintah telah mengeluarkan himbauan kepada masyarakat untuk mengikuti protokol kesehatan tersebut. Berbagai poster dan video edukasi telah dipublikasikan secara luas di media sosial, stasiun televisi, dan media komunikasi lainnya. Salah satu program yang selalu disosialisasikan oleh pemerintah pada masa pandemi ini adalah penerapan Perilaku Hidup Bersih dan Sehat (PHBS). Tujuan dari program Kuliah Kerja Nyata Pengabdian Pada Masyarakat Integratif Virtual ini adalah untuk mengetahui tingkat pengetahuan masyarakat mengenai pentingnya perilaku hidup bersih dan sehat dan bepergian di masa pandemi khususnya di era Adaptasi Kebiasaan Baru (AKB). Metode yang digunakan pada kegiatan 
ini yaitu, survey mengenai PHBS masyarakat, survey mengenai aktivitas berpergian selama pandemi, pembutan video dan poster PHBS, serta webinar mengenai pemanfaatan herbal sebagai antistress dan peningkat imunitas. Masyarakat mitra dalam kegiatan KKN PPM secara daring ini adalah masyarakat desa langensari kecamatan solokanjeruk pada khususnya dan masyarakat umum yang bisa mengakses media sosial. Hasil survey berpergian yaitu dari 441 responden sekitar 332 orang tidak memiliki rencana untuk melakukan traveling/berpergian. Dari 332 responden yang memilih tidak berpergian, sekitar 229 responden beralasan belum memiliki kepentingan yang krusial, 142 responden khawatir tertular COVID-19, 50 responden beralasan tidak memiliki akomodasi, dan 102 responden memilih untuk tetap melakukan traveling/berpergian. Hasil survey PHBS yaitu Sebagian besar responden telah menerapkan PHBS dengan hasil terbanyak adalah 99.3\% yaitu pada pilihan mencuci tangan dan menggunakan masker. Responden yang menjawab tidak pada pertanyaan ketiga memberi jawaban penyebab hal tersebut berupa karena kurang akses informasi $(3.4 \%)$, malas (6.9\%), dan kurang peduli (4.1\%). Kegiatan kelompok 25 KKN-PPM Integratif Virtual telah dilaksanakan dengan baik dan dapat meningkatkan pengetahuan masyarakat PHBS serta protokol kesehatan ketika bepergian di masa pandemic serta meningkatkan pengetahuan mengenai pemanfaatan dan pembuatan herbal untuk meningkatkan imunitas.

Kata kunci : Pengetahuan, Protokol kesehatan, Pandemi COVID-19, Bepergian Ketika Pandemi,

\section{PENDAHULUAN}

Beberapa kasus pneumonia yang tidak jelas diketahui penyebabnya telah dilaporkan oleh World Health Organization (WHO) China Country Office di Kota Wuhan, Cina pada bulan Desember 2019. Angka pertumbuhan jumlah kasus COVID-19 sendiri kian bertambah setiap harinya sehingga pada 30 Januari 2020, kasus COVID-19 ini sebagai Public Health Emergency of International Concern atau Kedaruratan Kesehatan Masyarakat yang Meresahkan Dunia (PHEIC/KKMMD). Penambahan yang berlangsung cukup pesat ini mengakibatkan ditetapkannya COVID-19 sebagai pandemi oleh WHO sejak 11 Maret 2020. Sedangkan di Indonesia sendiri, kasus pertama COVID-19 dilaporkan pada 2 Maret 2020. Hingga 7 Agustus 2020 tercatat jumlah kasus COVID-19 di Indonesia telah mencapai angka 121,226 terkonfirmasi positif, 38,076 pasien dalam perawatan, 77,557 sembuh, dan 5,593 meninggal dunia (CDC, 2020; WHO, 2020).

Virus penyebab COVID-19 dinamakan Severe Acute Respiratory Syndrome Coronavirus 2 (SARS-CoV-2) oleh International Committee on Taxonomy of Viruses di tanggal 11 Februari 2020. Adapun SARS-CoV-2 diketahui merupakan salah satu bagian dari keluarga coronavirus seperti virus penyebab Middle East Respiratory Syndrome (MERS) dan Severe Acute Respiratory Syndrome (SARS). Berdasarkan hasil penelitian, reseptor dari virus ini terdapat pada AngiotensinConverting Enzyme 2 (ACE2) yang dihasilkan pada sel epitel alveoli paru sehingga salah satu manifestasi dari infeksi COVID-19 adalah terjadinya gangguan fungsi paru pada pasien yang terinfeksi. Gejala pada pasien yang terinfeksi dapat berupa gejala ringan maupun berat. Umumnya tanda dan gejala yang muncul akibat infeksi COVID-19 antara lain gangguan pernapasan akut, batuk, demam, dan sesak nafas. Dari pemeriksaan beberapa kasus COVID-19 didapat hasil rontgen yang menunjukkan infiltrat pneumonia luas di kedua paru pasien ( Sun, 2020). Virus ini juga dapat menyebabkan sindrom pernafasan akut, pneumonia, gagal ginjal, dan bahkan kematian pada kasus yang berat. Masa inkubasi virus setelah infeksi ratarata 5-6 hari dengan inkubasi terpanjang 14 hari. Virus COVID19 dapat menyebar dari satu orang ke orang lainnya melalui droplet yang dikeluarkan oleh orang yang terinfeksi ketika batuk ataupun bersin. Selain itu seseorang juga dapat terinfeksi apabila terpapar permukaan benda yang terkontaminasi oleh virus kemudian virus masuk melalui mulut, hidung, kulit, ataupun bagian mata ( $\mathrm{Su}, 2020)$.

Berdasarkan pedoman transmisi COVID-19 terbaru yang dikeluarkan WHO menunjukkan adanya kemungkinan penularan melalui aerosol seperti saat latihan paduan suara, di restoran, atau di ruangan gym. Namun, perlu diadakan penelitian kembali mengenai transmisi aerosol ini (WHO, 2020).

Melihat perkembangan pandemi COVID-19 dan angka kasus baru yang kian meningkat WHO telah mengeluarkan beberapa protokol kesehatan. Protokol ini bertujuan untuk mencegah penyebaran infeksi virus. Beberapa standar rekomendasi untuk mencegah penyebaran infeksi ini antara lain, selalu membiasakan mencuci tangan secara teratur, menghindari menyentuh mata, hidung, dan mulut, menerapkan etika batuk dan bersin yang baik dengan menutup bagian hidung dan mulut dengan lengan atas atau tisu, memakai masker jika memiliki gejala pernapasan, menghindari kontak dengan orang lain (minimal 1 meter) yang menunjukkan gejala penyakit pernapasan, dan menghindari kontak dekat dengan hewan ternak serta hewan liar. Di Indonesia sendiri, pemerintah 
telah mengeluarkan himbauan kepada masyarakat untuk mengikuti protokol kesehatan tersebut. Berbagai poster dan video edukasi telah dipublikasikan secara luas di media sosial, stasiun televisi, dan media komunikasi lainnya (Kemenkes, 2020; Gugus Tugas 2020).

Salah satu program yang selalu disosialisasikan oleh pemerintah pada masa pandemi ini adalah penerapan Perilaku Hidup Bersih dan Sehat (PHBS). PHBS merupakan salah satu usaha untuk menularkan pengalaman mengenai perilaku hidup sehat melalui individu, kelompok maupun masyarakat luas dengan jalur-jalur komunikasi sebagai media berbagi informasi. Adapun tujuan dari PHBS salah satunya adalah mencegah timbulnya dan menanggulangi penyakit serta masalah-masalah kesehatan lain dalam rangka meningkatkan derajat kesehatan dengan tujuan utama hidup bersih dan sehat (Kemenkes PHBS, 2017)

Selama masa pandemi COVID-19, beberapa daerah di Indonesia telah menerapkan Pembatasan Sosial Berskala Besar (PSBB) .Masyarakat dihimbau untuk membatasi aktivitas di luar rumah (social distancing) jika tidak memiliki keperluan khusus yang mendesak. Masyarakat hanya boleh keluar rumah ketika untuk keadaan genting saja dan wajib mematuhi protokol yang telah ada seperti memakai masker dan physical distancing. Dalam hal itu, masih banyak oknum yang melanggar peraturan pemerintah. Beberapa dari mereka ada yang keluar rumah tidak dalam keadaan genting dan tidak menggunakan masker sesuai dengan protokol. Akan tetapi, banyak juga yang taat dan patuh kepada pemerintah untuk tetap karantina di rumah. Namun seiring berjalannya waktu, karantina membuat kondisi ekonomi masyarakat menjadi sulit.

Terhitung sejak bulan Juni 2020 pemerintah memberlakukan sistem $A K B$, yaitu masyarakat telah dibolehkan untuk keluar rumah dan kembali ke aktivitas seperti biasa namun dengan tatanan kehidupan baru yaitu tetap mematuhi protokol kesehatan yang telah ada. Dalam kondisi AKB tersebut, masyarakat yang telah lama bosan berada di dalam rumah, mencari hiburan dengan melakukan berbagai kegiatan di luar rumah. Salah satunya adalah bepergian yang telah menjadi gaya hidup masyarakat saat ini. Baik bepergian di dalam kota, keluar kota, maupun keluar provinsi yang tentu sebaiknya bukan ke daerah dengan tingkat zona merah terhadap peningkatan COVID-19. Untuk memahami dan mentaati protokol kesehatan yang ada, tentu tidak semua masyarakat dapat mengetahui, memahami bahkan mentaati protokol tersebut. Berdasarkan yang dikutip pada Centers for Disease Control and Prevention, protokol kesehatan yang harus dipatuhi ketika melaksanakan bepergian adalah, menggunakan masker yang menutupi hidung dan mulut, menghindari kontak dekat dengan orang lain, sering mencuci tangan atau menggunakan pembersih, hindari kontak dengan orang yang sedang sakit, dan hindari menyentuh mata, hidung dan mulut ( CDC, 2020; Gugus Tugas 2020).

Tujuan dari program Kuliah Kerja Nyata Pengabdian Pada Masyarakat (KKN-PPM) Integratif Virtual ini adalah untuk mengetahui tingkat pengetahuan masyarakat mengenai pentingnya PHBS dan bepergian di masa pandemi khususnya di era $A K B$. Selain itu dengan diadakannya kegiatan KKN-PPM ini diharapkan dapat menambah pengetahuan dan wawasan masyarakat mengenai COVID-19 dan pentingnya penerapan PHBS pada kehidupan sehari-hari.

\section{METODE}

Bentuk kegiatan pengabdian masyarkat ini adalah kuliah kerja nyata (KKN), adapun metode yang digunakan dalam proses pengabdian kepada masyarakat adalah sebagai berikut:

1. Mengadakan survey mengenai pengetahuan masyarakat akan pentingnya PHBS di era AKB, survey dilakukan secara online menggunkan gform, diisi oleh rekan dan masyarakat anggota KKN.

2. Mengadakan survey mengenai pengetahuan masyarakat tentang protokol kesehatan ketika bepergian di masa pandemic, survey dilakukan secara online menggunkan gform, diisi oleh rekan dan masyarakat anggota KKN.

3. Membuat poster dan video edukasi mengenai COVID-19 dan PHBS yang diposting melalui Youtube dan Instagram.

4. Mengadakan webinar mengenai COVID-19, penggunaan masker, dan pemanfaatan dan pembuatan sediaan herbal anti stress dan peningkatn imunitas.

\section{HASIL DAN PEMBAHASAN}

Pelaksanaan KKN-PPM berlangsung sejak tanggal 1 sampai 30 Juli 2020. Persiapan dan pelaksanaan kegiatan dilakukan secara daring dikarenakan adanya pandemi COVID19 yang tidak memungkinkan dilaksanakannya kegiatan tatap muka dengan mengumpulkan massa. Bentuk dari kegiatan ini berupa pembuatan dan publikasi poster dan video edukasi mengenai PHBS dan pandemi COVID-19 yang diunggah di akun Instagram dan Youtube kelompok KKN-PPM 25 selama bulan Juli 2020 serta webinar melalui aplikasi Zoom dan Youtube yang dilaksanakan pada tanggal 17 Juli 2020. Pengambilan data untuk mengetahui tingkat pengetahuan 
masyarakat diambil melalui kuesioner yang bertemakan PHBS dan Pemahaman Bepergian pada Fase $A K B$.

Partisipan edukasi webinar berjumlah 82 orang yang terdiri dari masyarakat umum dan komunitas target yaitu masyarakat Desa Langensari, Kecamatan Solokan Jeruk, Kabupaten Bandung. Secara umum, antusiasme para peserta sangat baik. hal ini ditunjukan dari keaktifan partisipan yang beberapa kali mengajukan dan menjawab pertanyaan. Kegiatan webinar pun berjalan dengan lancar.

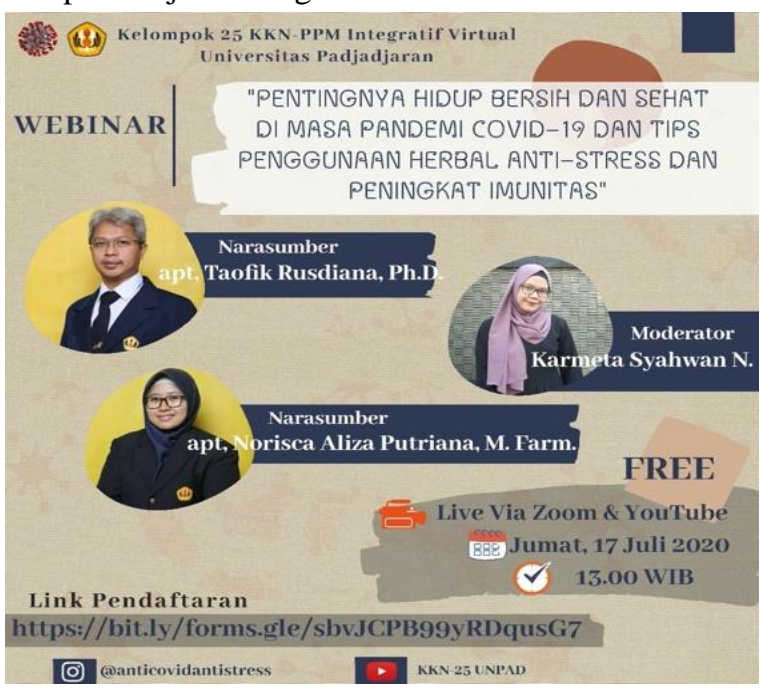

Gambar 1. Poster kegiatan webinar

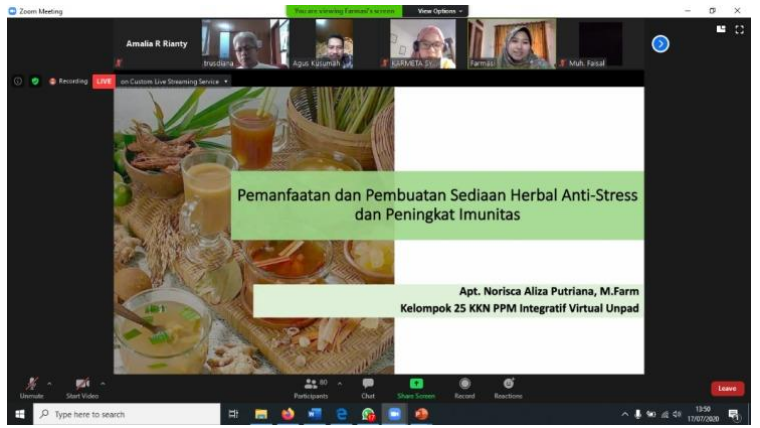

Gambar 2. Foto kegiatan webinar

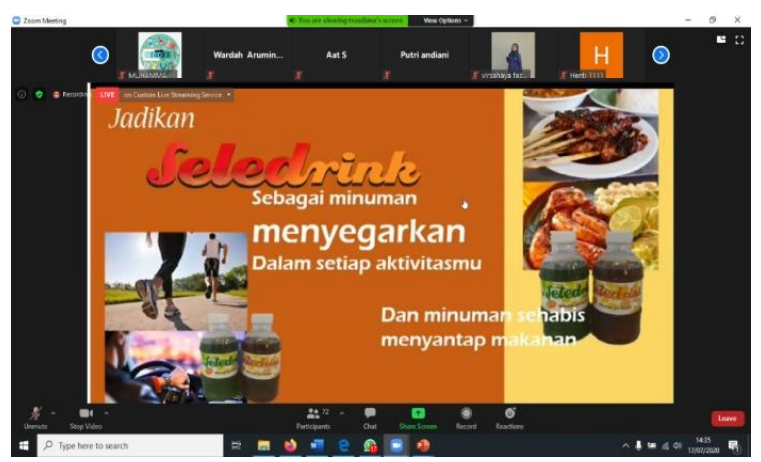

Gambar 3. Foto kegiatan webinar

\section{Hasil Survey Pemahaman Bepergian pada Fase $A K B$.}

Berdasarkan kuisioner yang telah disebar mengenai pemahaman bepergian pada fase AKB didapati 441 responden yang berasal dari berbagai daerah di Indonesia. Adapun usia responden bervariasi mulai dari 15-70 tahun. Hasil survei tersebut dapat dikatakan bahwa sebagian besar responden telah paham tentang protokol kesehatan ketika bepergian di masa pandemi. Namun, masih ada sebagian kecil responden yang belum paham mengenai protokol kesehatan ketika bepergian di masa pandemi.

441 responden sekitar 332 orang tidak memiliki rencana untuk melakukan traveling/berpergian. Dari 332 responden yang memilih tidak berpergian, sekitar 229 responden beralasan belum memiliki kepentingan yang krusial, 142 responden khawatir tertular COVID-19, 50 responden beralasan tidak memiliki akomodasi, dan 102 responden memilih untuk tetap melakukan traveling/berpergian.

Dalam survey ini dapat dinyatakan bahwa masih banyak responden yang memilih untuk tetap berada dirumah karena tidak memiliki kepentingan yang mendesak. Dari 102 responden yang memilih melakukan traveling/berpergian, 47 responden menyatakan bahwa mereka bosan berada dirumah, 54 responden menyatakan mereka memiliki agenda yang tidak bisa ditunda, 61 responden menyatakan memiliki tuntutan pekerjaan yang mengharuskan mereka untuk berpergian, mulai banyak responden yang merasa bosan dirumah dan ingin berbergian, dan alasan lainnya mereka berpergian karena memiliki kepentingan yang krusial seperti ujian masuk kuliah, melakukan penelitian.

Sekitar 93 responden yang ingin berpergian menyatakan ingin traveling/berpergian ke luar kota, 71 responden menyatakan ingin traveling di dalam kota saja, 34 responden menyatakan ingin ke luar provinsi, dan sekitar 32 responden ingin berpergian ke luar pulau dan luar negeriSekitar 423 responden merasakan adanya perbedaan dari segi persiapan ketika ingin berpergian di masa pandemik. 
Tabel 1. Hasil Survey mengenai Pemahaman Bepergian pada Fase $A K B$

\begin{tabular}{|c|c|c|c|}
\hline \multirow{2}{*}{\multicolumn{2}{|c|}{ Pertanyaan dalam Kuesioner }} & \multicolumn{2}{|c|}{ Jumlah } \\
\hline & & \multirow{2}{*}{$\begin{array}{l}\mathrm{n}= \\
441\end{array}$} & \multirow[t]{2}{*}{$\%$} \\
\hline \multirow[t]{3}{*}{1.} & $\begin{array}{l}\text { Tingkat rencana bepergian selama } \\
\text { masa pandemi }\end{array}$ & & \\
\hline & $\mathrm{Ya}$ & 109 & $25 \%$ \\
\hline & Tidak & 332 & $75 \%$ \\
\hline \multirow[t]{6}{*}{2.} & $\begin{array}{l}\text { Alasan tidak bepergian selama masa } \\
\text { pandemi }\end{array}$ & & \\
\hline & Belum memiliki kepentingan & 229 & $43 \%$ \\
\hline & Khawatir tertular COVID-19 & 142 & $27 \%$ \\
\hline & Tidak memiliki akomodasi & 50 & $9 \%$ \\
\hline & Memilih ya & 102 & $19 \%$ \\
\hline & Lainnya & 8 & $2 \%$ \\
\hline \multirow[t]{6}{*}{3.} & Alasan bepergian selama pandemi & & \\
\hline & Bosan di rumah & 47 & $10 \%$ \\
\hline & Agenda tidak bisa ditunda & 54 & $12 \%$ \\
\hline & Tuntutan pekerjaan & 61 & $13 \%$ \\
\hline & Memilih tidak & 266 & $57 \%$ \\
\hline & Lainnya & 35 & $8 \%$ \\
\hline \multirow[t]{6}{*}{4.} & Tujuan bepergian selama pandemi & & \\
\hline & Dalam kota & 71 & $14 \%$ \\
\hline & Luar kota & 93 & $19 \%$ \\
\hline & Luar provinsi & 34 & $7 \%$ \\
\hline & Luar pulau & 15 & $3 \%$ \\
\hline & Luar negeri & 17 & $3 \%$ \\
\hline \multirow[t]{3}{*}{5.} & $\begin{array}{l}\text { Perbedaan dari segi persiapan ketika } \\
\text { bepergian di masa pandemi }\end{array}$ & & \\
\hline & $\mathrm{Ya}$ & 423 & $96 \%$ \\
\hline & Tidak & 18 & $4 \%$ \\
\hline \multirow[t]{3}{*}{6.} & $\begin{array}{l}\text { Tingkat pemahaman protokol } \\
\text { kesehatan saat bepergian }\end{array}$ & & \\
\hline & $\mathrm{Ya}$ & 432 & $98 \%$ \\
\hline & Tidak & 8 & $2 \%$ \\
\hline \multirow[t]{8}{*}{7.} & $\begin{array}{l}\text { Persiapan yang dilakukan saat } \\
\text { bepergian di masa pandemi }\end{array}$ & & \\
\hline & Menggunakan masker & 428 & $20 \%$ \\
\hline & Membawa handsanitizer & 389 & $18 \%$ \\
\hline & Membawa kendaraan pribadi & 317 & $15 \%$ \\
\hline & Membawa bekal makanan & 270 & $13 \%$ \\
\hline & Menjaga kesehatan & 387 & $18 \%$ \\
\hline & Mengkonsumsi suplemen kesehatan & 301 & $14 \%$ \\
\hline & Lainnya & 60 & $3 \%$ \\
\hline
\end{tabular}

Sekitar 432 responden mengetahui dan paham mengenai protokol kesehatan ketika ingin berpergian selama masa pandemik. Selama berpergian di masa pandemik ini responden menyatakan mereka menggunakan masker membawa handsanitizer, memilih untuk membawa kendaraan pribadi, membawa bekal makan sendiri, selalu menjaga kesehatan dan mengkonsumsi suplemen kesehatan.

Dari survey yang kami lakukan, kami masih banyak menemukan responden yang ingin berpergian/liburan hanya karena bosan dirumah. Kami ingin memberikan saran bahwa masih banyak kegiatan yang bisa dilakukan walaupun dirumah saja, seperti mencoba resep masakan baru, bercocok tanam, bermain musik, bermain game, bahkan olahraga pun bisa dilakukan walau hanya dirumah. Jika sangat diharuskan untuk berpergian, maka kami menyarankan untuk selalu memperhatikan protokol kesehatan dengan menggunakan masker, membawa handsanitizir, membawa peralatan makan/minum sendiri, memggunakan kendaraam pribadi dan selalu melakukan social distancing.

\section{Hasil Survey PHBS}

Berdasarkan kuesioner yang telah disebar mengenai PHBS di dapat 145 responden yang berasal dari berbagai daerah di Indonesia. Adapun usia responden yang telah mengisi kuesioner tersebut bervariasi mulai dari 16-23 tahun.

Pada Tabel 2 proposi responden yang menjawab ya pada pertanyaan nomer 1 adalah $98.6 \%$ dan yang menjawab tidak adalah $1.4 \%$. Responden menilai tingkat pemahaman mengenai PHBS dalam skala 1 sampai 5 dan didapati hasil sebagian besar memilih skala $3(24.8 \%)$, $4(54.5 \%)$, dan $5(19.3 \%)$ sedangkan skala $2(19.3 \%)$. Sebanyak 145 responden (100\%) menjawab ya pada pertanyaan ketiga mengenai pentingnya PHBS dalam kehidupan $A K B$ selama pandemi COVID-19. Sebagian besar responden telah menerapkan PHBS dengan hasil terbanyak adalah $99.3 \%$ yaitu pada pilihan mencuci tangan dan menggunakan masker. Responden yang menjawab tidak pada pertanyaan ketiga memberi jawaban penyebab hal tersebut berupa karena kurang akses informasi $(3.4 \%)$, malas $(6.9 \%)$, dan kurang peduli (4.1\%). Dari hasil yang didapat, hampir semua responden telah mengetahui apa itu PHBS dan menerapkannya dalam kehidupan sehari-hari. Hal tersebut juga dipengaruhi oleh tingkat pemahaman dan pandangan responden mengenai pentingnya penerapan PHBS Seperti hasil yang diperoleh dari pertanyaan kedua, semua responden berpendapat penting untuk dilakukannya penerapan PHBS dalam kehidupan AKB selama pandemi COVID-19. 
Tabel 2. Hasil Survey Mengenai PHBS

\begin{tabular}{|c|c|c|c|}
\hline & & Jun & lah \\
\hline & & $n=145$ & $\%$ \\
\hline 1 & $\begin{array}{l}\text { Apakah anda mengetahui apa itu } \\
\text { PHBS? } \\
\text { Ya } \\
\text { Tidak }\end{array}$ & $\begin{array}{c}143 \\
2\end{array}$ & $\begin{array}{c}98.6 \% \\
1.4 \%\end{array}$ \\
\hline 2 & $\begin{array}{l}\text { Seberapa paham anda mengenai PHBS? } \\
\text { (skala 1-5) } \\
\qquad \begin{array}{l}1 \\
2 \\
3 \\
4 \\
5\end{array}\end{array}$ & $\begin{array}{c}0 \\
2 \\
36 \\
79 \\
28\end{array}$ & $\begin{array}{l}0 \% \\
1.4 \% \\
24.8 \% \\
54.5 \% \\
19.3 \%\end{array}$ \\
\hline 3 & $\begin{array}{l}\text { Apakah anda merasa PHBS penting } \\
\text { dalam kehidupan } A K B \text { selama Pandemi } \\
\text { COVID-19? } \\
\text { Ya } \\
\text { Tidak }\end{array}$ & $\begin{array}{c}145 \\
0\end{array}$ & $\begin{array}{c}100 \% \\
0 \%\end{array}$ \\
\hline 4 & $\begin{array}{l}\text { Apabila Ya, PHBS apa saja yang sudah } \\
\text { anda terapkan setiap hari di era } A K B \\
\text { selama Pandemi COVID-19? }\end{array}$ & & \\
\hline & Cuci tangan & 144 & $99.3 \%$ \\
\hline & Menggunakan masker & 144 & $99.3 \%$ \\
\hline & Social distancing & 127 & $87.6 \%$ \\
\hline & Olahraga teratur & 52 & $35.9 \%$ \\
\hline & $\begin{array}{l}\text { Menggunakan jamban bersih dan } \\
\text { sehat }\end{array}$ & 121 & $83.4 \%$ \\
\hline & Tidur yang cukup & 83 & $57.2 \%$ \\
\hline & $\begin{array}{l}\text { Mengonsumsi makanan bergizi, } \\
\text { buah, dan sayur }\end{array}$ & 102 & $70.3 \%$ \\
\hline & Membersihkan lingkungan & 104 & $71.7 \%$ \\
\hline & Tidak merokok dan minum alkohol & 123 & $84.8 \%$ \\
\hline & Keluar rumah seperlunya & 1 & $0.7 \%$ \\
\hline & Di rumah saja & 1 & $0.7 \%$ \\
\hline & $\begin{array}{l}\text { Menjaga mental health agar tidak } \\
\text { stress }\end{array}$ & 1 & $0.7 \%$ \\
\hline & $\begin{array}{l}\text { Apabila tidak, apa penyebabnya? } \\
\text { Kurang akses informasi } \\
\text { Malas } \\
\text { Kurang peduli } \\
\text { (Saya menjawab Ya) } \\
\text { Alhamdulillah ditempat saya tidak } \\
\text { ada sibuk untuk } \\
\text { Terlalu } \\
\text { menyempatkan berolahraga } \\
(-)\end{array}$ & $\begin{array}{c}5 \\
10 \\
6 \\
129 \\
1 \\
1 \\
1\end{array}$ & $\begin{array}{l}3.4 \% \\
6.9 \% \\
4.1 \% \\
89 \% \\
0.7 \% \\
0.7 \% \\
0.7 \%\end{array}$ \\
\hline
\end{tabular}

Namun dalam pelaksanaannya terdapat beberapa responden yang belum menerapkan PHBS. Pemberian informasi yang akurat dan jelas kepada masyarakat tetap perlu dilakukan untuk meningkatkan pemahaman dan kepedulian masyarakat akan pentingnya pelaksanaan PHBS khususnya di pandemi COVID - 19 ini.

\section{Faktor Pendorong dan Penghambat}

Faktor pendorong program terhadap kegiatan KKNPPM ini adalah berupa sikap mahasiswa dan dosen pembimbing lapangan yang interaktif serta keinginan dalam memberikan informasi mengenai PHBS kepada masyarakat. Sedangkan, yang menjadi faktor penghambat dalam menjalankan kegiatan KKN-PPM adalah sedikit terhambatnya komunikasi yang dilakukan karena pertemuan hanya bisa dilakukan melalui pertemuan secara virtual.

Walaupun kegiatan KKN-PPM ini dilaksanakan secara virtual, pelaksanaan kegiatan KKN-PPM ini mendapatkan sambutan yang baik oleh masyarakat setempat serta Bapak Kades yang ikut langsung dan memberikan sambutan pada kegiatan webinar tersebut. Bapak Kades juga menghimbau kepada warganya agar tetap mematuhi perilaku pola hidup bersih dan sehat (PHBS) selama masa pandemi ini.

\section{KESIMPULAN}

Kegiatan kelompok 25 KKN-PPM Integratif Virtual telah dilaksanakan dengan baik dan lancar serta dapat meningkatkan pemahaman dan pengetahuan masyarakat mengenai pola hidup bersih dan sehat (PHBS) serta protokol kesehatan ketika bepergian di masa pandemi. Perubahan yang diharapkan dari diadakannya kegiatan KKN-PPM ini adalah Pemahaman yang luas oleh partisipan webinar mengenai perilaku hidup bersih dan sehat (PHBS) dan pemahaman yang luas dan perilaku yang patuh oleh partisipan webinar terhadap protokol kesehatan ketika bepergian pada fase AKB.

\section{UCAPAN TERIMAKASIH}

Penulis menghaturkan terimakasih kepada Bapak Kepala Desa Langensari yang telah bersedia menfasilitasi komunitas virtual warganya sebagai audien dan sasaran survey dalam kegiatan KKN-PPM ini serta membantu kelancaran dalam terselenggarakannya program ini, juga terimakasih kepada anggota tim KKN Virtual 25 Universitas Padjadajaran

\section{DAFTAR PUSTAKA}

CDC. (2020), "Coronavirus Disease 2019 (COVID-19) Centers for Disease Control and Prevention. Tersedia $\mathrm{di}$ : https://www.cdc.gov/coronavirus/2019 ncov/travelers/travelduring-covid19.html (Diakses: 11Februari2020). 
Gugus Tugas Percepatan Penanganan COVID-19. (2020). Peta Sebaran. Tersedia di : https://covid19.go.id/peta-sebaran. (Diakses: 7Agustus2020)

Gugus Tugas Percepatan Penanganan COVID-19. (2020). Pedoman Penanganan Cepat Medis Dan Kesehatan Masyarakat COVID-19 Di Indonesia - Protokol | Gugus Tugas Percepatan PenangananCOVID-19.Covid19.Go.Id.Tersdia

di:https://covid19.go.id/p/protokol/pedoman-penanganan-cepatmedis-dan-kesehatan-masyarakat-covid-19-di-indonesia.

(Diakses 2 Sept. 2020)

Kementrian Kesehatan Republik Indonesia. (2020). Pedoman Pencegahan dan Pengendalian Coronavirus Disease 2019 (COVID-19). Tersedi di : covid19.kemkes.go.id/situasi-infeksiemerging/info-corona-virus/situasi-terkini-perkembangan-covid19-17-maret-2020/\#.XnIT1qgzbIU. (Diakses 18 Maret 2020)

Sun P, Lu X, Xu C, Sun W, Pan B. (2020). Understanding of COVID 19 Based on Current Evidence. J Med Virol, 2, p 10-3

Su L, Ma X, Yu H, Zhang Z, Bian P, Han Y, et al. (2020). The different clinical characteristics of corona virus disease cases between children and their families in China-the character of childrenwithCOVID2019.https://doi.org/10.1080/22221751.2020 .1744483

World Health Organization (WHO). (2020). Corona Disease (COVID19)SituarionReport.tersediadi.https://www.who.int/docs/ default-source/searo/indonesia/covid19/who-situation-report10.pdf?sfvrsn=a9ceb157_2. (Diakses 30 Agustus 2020) 